\title{
Two new Typhloreicheia species from Sardinia and their biogeographical significance (Coleoptera, Carabidae, Scaritinae)
}

\author{
Achille Casale ${ }^{\dagger}$ Paolo Marcia ${ }^{\ddagger}$ \\ Dipartimento di Zoologia e Genetica Evoluzionistica, Università di Sassari, Via Muroni 25, 07100 \\ Sassari (Italy) \\ † urn:lsid:zoobank.org:author:7488DBB2-9447-4698-8613-5E90D5C7228D \\ † urn:lsid:zoobank.org:author:505E7088-28A6-46BA-88BD-9343C99BC36E \\ Corresponding author: Paolo Marcia (casale@uniss.it)
}

Academic editor: Augusto Taglianti | Received 13 June 2011 | Accepted 2 August 2011 | Published 6 October 2011

urn:lsid:zoobank.org:pub:0B88CDFB-8FB6-4915-8130-A545F019CC07

Citation: Casale A, Marcia P (2011) Two new Typhloreicheia species from Sardinia and their biogeographical significance (Coleoptera, Carabidae, Scaritinae). ZooKeys 134: 15-31. doi: 10.3897/zookeys.134.1707

\begin{abstract}
Typhloreicheia monacha sp. n. and T. ilianae sp. n. are described from two caves of Central-Eastern Sardinia (Nuoro province): the Bue Marino cave and the Nurra 'e Pradu cave, respectively. Both caves are located in the part of the island where many highly specialised subterranean carabid beetles are localised. T. monacha is apparently related to two other species of the same area, i.e. T. onnisi Casale \& Magrini, 2004 and T. elegans (Dodero, 1916); T. ilianae is closely related to T. henroti Jeannel, 1957, known from a cave near Dorgali. Relationships and diagnostic features among these taxa are discussed and illustrated, and a key for identification of the specialised subterranean Typhloreicheia species of Sardinia is provided. The hypothesis of adaptive radiation of Reicheiina species in Sardinia, recently proposed by the senior author of this contribution, is further elaborated in light of new data.
\end{abstract}

\section{Keywords}

Coleoptera, Carabidae, Scaritinae, Typhloreicheia, new species, Sardinia, adaptive radiation 


\section{Introduction}

The subtribe Reicheiina is a lineage of endogean and hypogean carabid beetles, currently classified in the tribe Clivinini of the subfamily Scaritinae of the family Carabidae (Vigna Taglianti 2005), including so far (as genera "close to Reicheia": Jeannel 1957) about 150 species (Balkenohl 2003, Lorenz 2005, Grebennikov et al. 2009). External structural attributes of Reicheiina are markedly homogeneous: most of the species are small-sized carabids (1-4 mm) with reduced or absent eyes, moniliform antennae, fossorial prothoracic legs (typical of Scaritinae), the posterior angles of pronotum obliterated and rounded, short pronotal peduncle and the lack of a basal annular constriction on the pronotum. A few taxa, such as the subterranean Spelaeodytes mirabilis L. Miller, 1863, living in caves of the Eastern Adriatic coast (Croatia), display markedly troglomorphic adaptive features (Casale et al. 1998 a, b).

Work with Reicheiina beetles is hampered by the small sizes of its representatives and by the scarcity of material, some taxa being known from one or a few specimens. Morphological characters currently employed in defining various members of Reicheiina are those of external body shape and male genitalia, while immature stages, for example, are still completely unknown.

Monophyly of Reicheiina has never been adequately demonstrated and a distinct possibility exists that the group is an artificial assemblage of unrelated subterranean scaritine clades (Grebennikov et al. 2009). Overall subtribe's existence and its current placement in the tribe Clivinini and generic composition are more a result of gradually evolving taxonomic treatment, initiated by Holdhaus (1924), Jeannel (1957) and Basilewsky (1980), rather than a reflection on its hypothesised monophyly.

However, the monophyly of the Euro-Mediterranean core of Reicheiina formed by the genus Typhloreicheia and its relatives is highly plausible. In Sardinia, the genus Typhloreicheia Holdhaus, 1924 is markedly diversified (Casale 2009). In this contribution, the authors describe two new morphologically specialized Typhloreicheia species from caves of Sardinia, and debate some biogeographical aspects of this discovery.

\section{Material and methods}

Newly designated Sardinian Typhloreicheia type specimens were collected during speleological or biospeleological investigations. All subsequent focused attempts to obtain further individuals by using pitfall traps or baits were unsuccessful.

Male genitalia were dissected, dehydrated in ethanol, cleared in cold $\mathrm{KOH}$, examined and illustrated, using standard techniques before their definitive inclusion on microscope slides attached to the respective specimens. Line drawings were made using a camera lucida attached to stereomicroscopes Wild M-5, and a microscope Leitz Orthoplan.

Photographs of male genitalia were prepared by Paolo Magrini (Florence), with a Nikon D1 digital camera mounted on a Nikon Labophot II binocular microscope. P. Magrini also prepared distributional maps of Typhloreicheia in Sardinia. 
The median lobe of aedeagus is synonym of phallus of authors. The proximal gonocoxite 1, and the more distal gonocoxite 2 (in the sense of Liebherr and Will 1998), are synonyms of stylomere 1 and stylomere 2 of authors, respectively.

Acronyms:

TL body Total length, from the anterior margin of clypeus to the apex of elytra, measured along the elytral suture.

L overall body length, from apex of mandibles to apex of elytra, measured along the suture.

PL/PW ratio length of Pronotum, as linear distance from the anterior to the posterior margin (peduncle included), measured along the midline to the maximum Width of Pronotum.

EL/EW ratio length of Elytra, as linear distance from the basal ridge to the apex, measured along the elytral suture to the maximum Width of Elytra.

EL/PW ratio maximum Width of Elytra to maximum Width of Pronotum

AL length of antenna.

Collections:

CCa all type specimens are preserved in Casale Collection (University of Sassari, Italy)

\section{Results}

\section{Typhloreicheia monacha sp. $\mathrm{n}$.}

urn:Isid:zoobank.org:act:D1845710-A731-46D0-9904-65DD4662188E

http://species-id.net/wiki/Typhloreicheia_monacha

Type locality. Italy, Central-Eastern Sardinia: Dorgali (Nuoro province), Cala Gonone: Bue Marino cave (speleological inventory number: 12 Sa/NU), 0 m a.s.l., $40^{\circ} 14^{\prime} 51^{\prime \prime} \mathrm{N}$ 93'ㄱ' 29

Type material. Holotype male with the following data: I - Sardegna, Dorgali (NU), Gr. Bue Marino 10.IX.2006 P. Marcia leg.; paratypes: female, same data as holotype; female: I - Sardegna, Urzulei (NU) Codula di Luna, Gr. Su Spiria 1988 Sa/ NU 23.VII.1995 R. Loru leg. (CCa).

Etymology. The Latin noun "monachus-a" (= monk) recalls the monk seal Monachus monachus (Hermann, 1779), the so-called "Bue Marino", in the tradition of the Mediterranean languages, from which the type locality cave derives its name. Monk seal is presently one of the most endangered mammalian species of the Mediterranean fauna, although it was still present in the Eastern coast of Sardinia until the '60s of the past century. 
Diagnosis. Typhloreicheia monacha new species, for both its external features and characteristics of male genitalia, seems to be related to T. onnisi Casale \& Magrini, 2004, known from three caves in the Gairo region (Central-Eastern Sardinia), and, to a lesser extent, to T. elegans (Dodero, 1916) known from a cave of Arcuerì Mt. near Seui. The male features of the latter, however, are still unknown.

From T. onnisi the new species can be distinguished mainly by its stouter and wider head, with more convex genae; by its wider pronotum, with anterior angles larger and more prominent, and lateral margins more rounded and less constricted toward the base; by the elytra shorter, with lateral margins with more numerous (23-25) (14-16 in T. onnisi) and more prominent marginal teeth; and by the different shape of the aedeagus (see Figures 3-4).

Description. A medium-large sized Typhloreicheia species (TL: 2.95-3.08 mm; L: 3.28-3.40 mm).

Body elongate, convex (Figure 1). Colour testaceous reddish, antennae and mouthparts slightly paler. Integument shiny, polished; microsculpure with fine, hardly visible microlines in form of isodiametric mesh pattern on head and elytra, almost vanished on pronotum.

Head with ocular part of genae regularly convex, constricted toward the neck. Eyes absent. Supra-antennal plates separated from genae by deep and broad furrow; frontal furrows very deep, transversally wrinkled; vertex with an evident, convex tubercle in the middle; antennae moderately elongate (AL: $1.31 \mathrm{~mm}$ in male holotype), antennomeres 3-10 slightly longer than wide.

Pronotum moderately convex, elongate (PL/PW: 1.0), with its maximum width at the anterior third; sides moderately rounded, slightly attenuated in front, markedly constricted to the basal peduncle; anterior angles acutely prominent; median furrow narrow and deeply impressed; lateral furrows very narrow and superficial.

Elytra elongate-ovate (EL/EW: 1.6), distinctly wider than pronotum (EW/PW: 1.21), convex, with their maximum width in the middle; humeri broadly rounded; lateral furrows wide, flattened, not narrowed at apex; lateral margin reflexed, with numerous (23-25), small but acutely prominent marginal teeth; striae all evident, deeply punctuate, gradually disappearing at apex; elytral intervals moderately convex, intervals 2-7 each bearing a series of short, erected setae; umbilicate series of 16-19 punctures along stria 8 .

Male genitalia as in Figure 3. Median lobe of aedeagus markedly curved, with short, rounded and flattened apex. Endophallus with developed, apical copulatory piece and an elongate packet of serrate scales in the middle. Parameres each with two apical setae.

Female genitalia (examined, not illustrated) without any peculiar characteristic: gonocoxites 2 rather short, regularly curved outwards, each with two moderately elongate, robust spiniform setae on the outer side, the distal of them being distinctly longer and thickener than the proximal one.

Distribution and habitat. Two specimens of $T$. monacha sp. n. were collected during one of bio-speleological expeditions organized in the last years by the authors. 


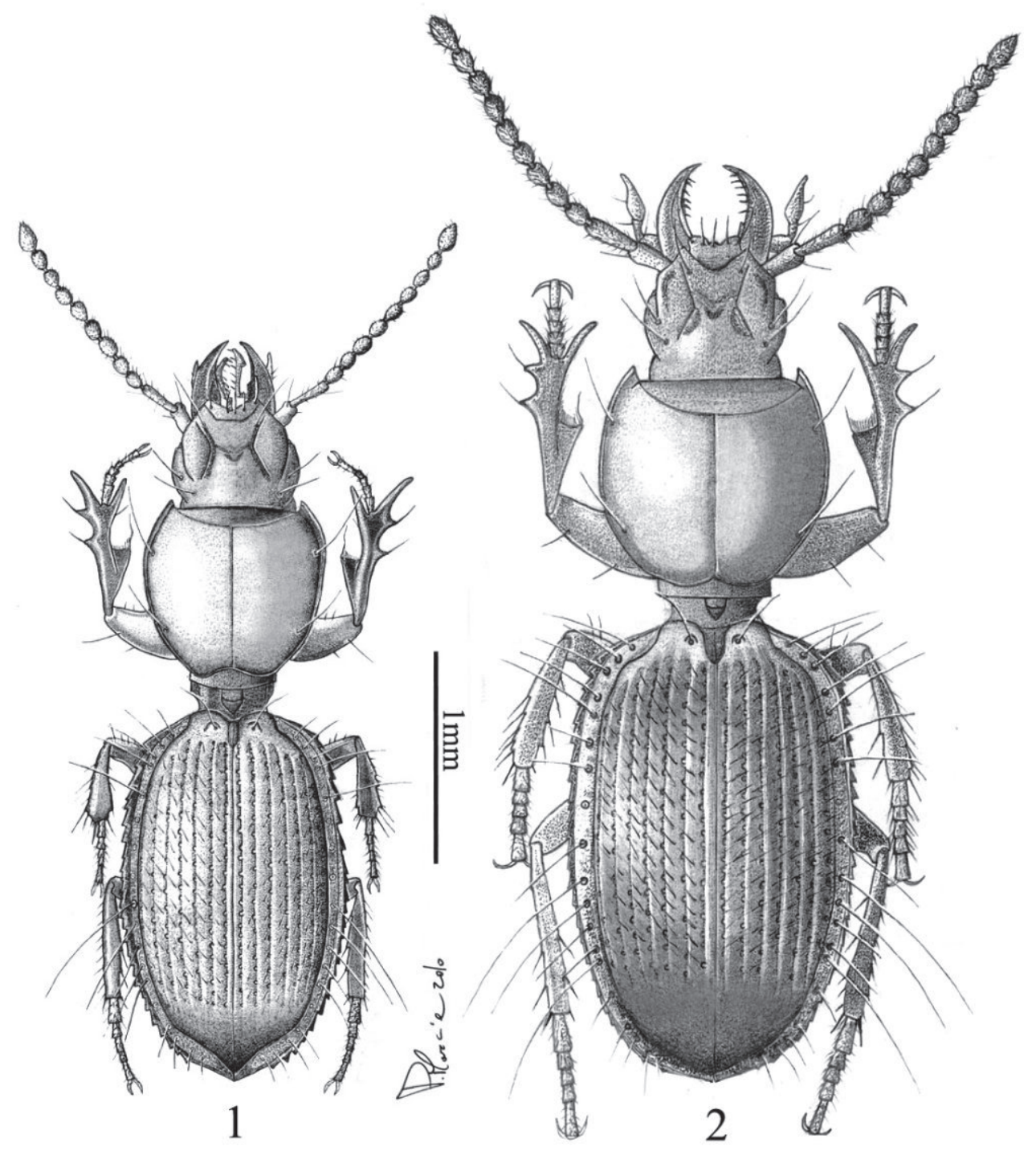

Figures I-2. Typhloreicheia monacha sp. n., male holotype, dorsal aspect $\mathbf{2}$ Typhloreicheia ilianae sp. n., male holotype, dorsal aspect.

The specimens were walking on sandy, humid soil on the banks of the subterranean lakes in the inner parts of the Bue marino cave, in the same habitat as those noted for the molopine carabid beetle Speomolops sardous Patrizi, 1955 and its larva (Casale et al. 2010). The Bue Marino cave, with 48 subterranean species reported so far, is the Sardinian cave richest in hypogean fauna (Casale et al. 2008). An additional female individual was collected by Roberto Loru in the same environmental conditions during a speleological exploration in the nearby Su Spiria cave (1988 Sa/NU) $40^{\circ} 10^{\prime} 42^{\prime \prime} \mathrm{N}-9^{\circ} 33^{\prime} 54^{\prime \prime} \mathrm{E}, 165 \mathrm{~m}$ a.s.l. (Urzulei, Codula Ilune, hypogean system of Su 
Palu - Grutta de Monte Longos caves), and was erroneously attributed to T. henroti (Casale \& Magrini 2004).

In spite of many subsequent investigations in both these caves, including setting pitfall traps, no further individuals of this species have been obtained. T. monacha, like other species of the same genus in Sardinia (and most so-called troglobiont species: Giachino \& Vailati 2010), seems to be a deep crevices dweller, which occasionally penetrate in large hypogean systems accessible to the humans, and are never collected by shifting soil.

Relationships. The following features of $T$. monacha sp. n. suggest its affinities with the elegans species group (Jeannel 1957; Casale and Magrini 2004): medium-large sized body, elytra with intervals 2-7 each bearing a series of erected setae and lateral margins serrate from the humeral angle to apex, shape of aedeagus and structure of endophallus. With the discovery of T. ilianae new species, however, this group appears non-monophyletic (see below, in relationships of T. ilianae). Therefore, T. elegans, T. onnisi and T. monacha sp. $\mathrm{n}$. are separated in the elegans species group (in the new sense) distinct from the henroti species group (see below).

\section{Typhloreicheia ilianae sp. $\mathrm{n}$.}

urn:lsid:zoobank.org:act:B5A1C382-9E73-4F50-B15A-611522B1F9A7

http://species-id.net/wiki/Typhloreicheia_ilianae

Type locality. Italy, Central-Eastern Sardinia: Oliena (Nuoro province), Corrasi Mt.: Nurra 'e Pradu cave (speleological inventory number: 3083 Sa/NU), $1220 \mathrm{~m}$ a.s.l. , $40^{\circ}$ $15^{\prime} 27.0 " \mathrm{~N}, 009^{\circ} 25^{\prime} 45.3 " \mathrm{E}$

Type material. Holotype male with the following data: I - Sardegna, Oliena (NU), M. Corrasi 26.I.2008 P. Marcia”, "Gr. Nurra 'e Pradu” (CCa).

Etymology. The name derives from the Oliena village at the base of the Corrasi mountain in which this new species, and many other hypogean organisms were discovered. An ancient legend says that the inhabitants (Ilienses in Latin) of Troy (Ilios in ancient Greek), after the fall of the town to the Greeks, reached Sardinia and founded a village named Iliana, which subsequently became Oliena.

Diagnosis. Typhloreicheia ilianae is the largest in size among the Sardinian congeners known so far, with its TL: 3.64 and L: 4.05 (male holotype). It is evidently related to T. henroti Jeannel, 1957 (see features of the median lobes of aedeagus in respective species: Figures 5-6), but can be distinguished from the latter mainly by its larger size (TL: $3.10-3.65$, L: 3.40 - 3.86 in T. henroti); by wider and more robust head, with supra-antennal plates more prominent laterally, by more convex genae markedly constricted to the neck, by antennomeres 3-11 more thickened, and by anterior angles of both clypeus and labrum more acutely prominent; and by the different shape of the median lobe of aedeagus (Figures 5-6).

Description. A large sized Typhloreicheia species (TL: 3.64; L: 4.05 mm, in male holotype). 


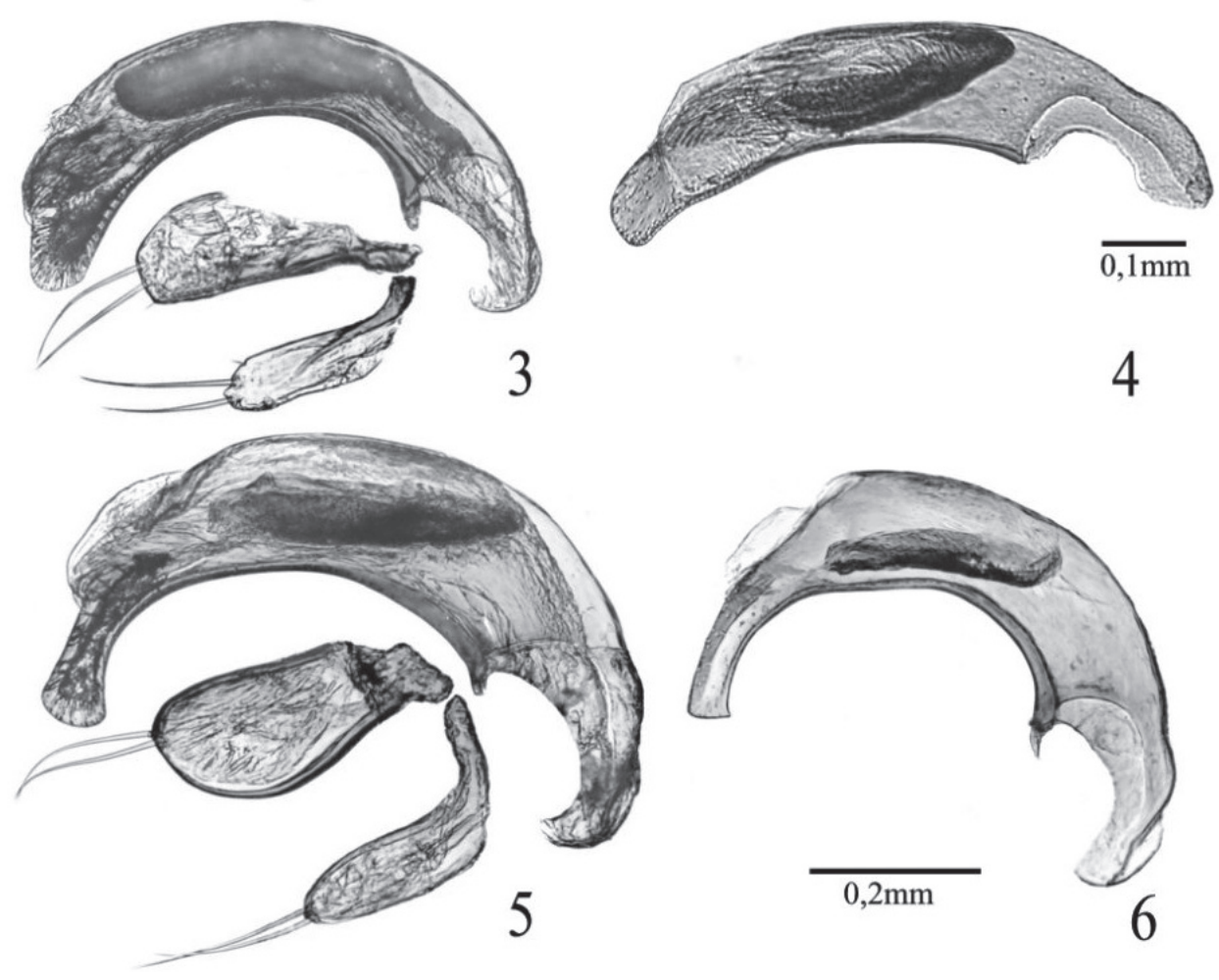

Figures 3-6. Typhloreicheia spp., male genitalia, right lateral aspect: 3 T. monacha sp. n., median lobe f aedeagus and parameres 4 T. onnisi Casale \& Magrini, median lobe of aedeagus 5 T. ilianae sp. n., median lobe of aedeagus and parameres $\mathbf{6}$ T. henroti Jeannel, median lobe of aedeagus.

Body elongate but robust, convex (Figure 2). Colour testaceous reddish, antennae and mouthparts slightly paler.

Integument shiny, highly polished; microsculpure with fine, hardly visible microlines in form of isodiametric mesh pattern on head and elytra, almost vanished on pronotum.

Head robust, with ocular part of genae markedly convex, constricted toward the neck. Eyes absent. Anterior angles of clypeus acutely prominent. Supra-antennal plates prominent laterally, with outer margin beaded, separated from genae by deep and broad furrow; frontal furrows very deep, with shallow wrinkles in the posterior tract; vertex with an evident, convex tubercle in the middle; antennae elongate (AL: $1.58 \mathrm{~mm}$ in male holotype) but robust, thickened; antennomeres 6-10 slightly longer than wide.

Pronotum markedly convex, relatively wide (PL/PW: 0.95), with its maximum width at the basal third; sides moderately rounded, slightly narrowed in front, markedly constricted to the basal peduncle; anterior angles acutely prominent; median furrow very shallow; lateral furrows very narrow and superficial.

Elytra elongate-ovate (EL/EW: 1.62), distinctly wider than pronotum (EW/PW: 1.24), convex, with their maximum width in the middle; humeri broadly rounded; 
lateral furrows wide, flattened, not narrowed at apex; lateral margin reflexed, elytra with lateral margins with numerous (24) prominent marginal teeth; striae deep, deeply punctuate, all evident, gradually disappearing et apex; elytral intervals convex, intervals 2-7 each bearing a series of short, erected setae; umbilicate series of 16-19 punctures along stria 8 .

Male genitalia as in Figure 5. Median lobe of aedeagus markedly curved, with long apical lamina, which is widened, hatched-like distally. Endophallus with a reduced, inconspicuous apical copulatory piece and an elongate packet of serrate scales in the middle. Parameres each with two apical setae.

Female genitalia: unknown.

Distribution and habitat. Typhloreicheia ilianae sp. n. is known only from the type locality. The holotype was sampled in wet soil under big stones in a small pit $(-3.7 \mathrm{~m})$, which represents the entrance of a large hypogean system, reaching the depth of $101 \mathrm{~m}$. The associated subterranean fauna includes some of the most specialised troglomorphic endemic Sardinian elements, such as Sardaphaenops supramontanus supramontanus Cerruti \& Henrot, 1956 (Coleoptera, Carabidae, Trechini) and Patriziella sardoa Jeannel, 1956 (Coleoptera, Cholevidae, Leptodirini), both described from a nearby cave Nurra 'e Sas Palumbas. The Nurra 'e Pradu cave is also one of the few localities of Sardinia from which the large sized, trogloxenic centipede Plutonium zwierleini Cavanna, 1881 is reported (Zapparoli 2009). We sampled in this cave the following taxa, all endemic to central-eastern Sardinia and representing new faunal records: the orthopteran Acroneuroptila cf. sardoa Baccetti, 1960, the sphodrine carabid beetle Laemostenus pippiai (G. Fiori, 1961) (A. Casale det.), the cholevid beetle Ovobathysciola majori (Reitter, 1885) (A. Casale det.), and the terrestrial snail Tacheocampylaea carotii (Paulucci 1882) (S. Birindelli det.). Subsequent trapping in this cave using pitfall traps, did not produce additional individuals of $T$. ilianae.

Relationships. Typhloreicheia ilianae is the largest among the Sardinian species known so far, exceeding the large size of $T$. kraussei (Reitter, 1914), a typical endogean, not hypogean species reaching $3.69 \mathrm{~mm}$ in length (Leo et al. 2005). Nevertheless, any relationship of T. ilianae sp. n. with T. kraussei (Reitter, 1914) and its adelphotaxon T. manto (Holdhaus, 1924), both typically endogean, not hypogean species, are highly unlikely. Both latter species have elytral setiferous pores present in intervals 2, 3, 5 and 7 only, and the lateral margins serrate only in the basal half. Furthermore, in these taxa the features of the median lobe of aedeagus are markedly dissimilar to those of $T$. ilianae sp. n., and the apical copulatory piece in endophallus is lacking in T. kraussei (Leo et al. 2005).

The new taxon appears related to T. henroti Jeannel, 1957, known from the Gurennoro cave (= Pisanu cave, $215 \mathrm{Sa} / \mathrm{NU}$, near Dorgali). Both species are similar in having large-sized body and elytral lateral margins bearing numerous (21-24) teeth extending all the way from the humeral angle to elytral apex. Also both species share the peculiar shape of the median lobe of aedeagus, which is unique among the Sardinian species (Figures 5-6). These species form a pair of adelphotaxa very isolated from the rest of species known so far on the island, here indicated as henroti species group, excluding 
the other specialised hypogean species of Sardinia known so far (T. elegans, T. onnisi, and T. monacha sp. n.) treated above as elegans species group in the narrow sense.

The following operative and provisional key is provided to distinguish the cave dweller (deep hypogean, or troglophilic) Typhloreicheia species known so far in Central Eastern Sardinia:

1 Larger in size (TL: mm 2.9-3.6; L: 3.0-4.0); elytra with intervals 2-7 all having setiferous punctures, and with lateral margins serrate from the humeral angle to apex. Deep hypogean species, known from caves only

- Smaller in size (TL less than $3 \mathrm{~mm}$ ); elytra with only intervals 2-3-5-7 having setiferous punctures. Endogean but troglophilic species, occasionally

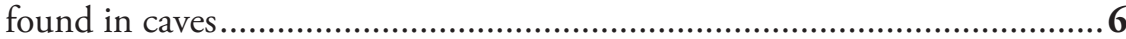

2 Larger in size (TL: 3.10-3.65; L: 3.40-4.05). Median lobe of aedeagus with apical lamina very elongate, spatulate or axe-shaped distally (henroti species group in new sense)

- $\quad$ Smaller in size (TL: 2.90-3.10; L: 3.00-3.40). Median lobe of aedeagus (in the two species in which it is known) with apical lamina short, rounded or sub-truncate distally (elegans species group in new sense) ........................4

3 Larger in size (TL: $3.64 \mathrm{~mm}$; L: $4.05 \mathrm{~mm}$, in male holotype). Median lobe of aedeagus larger, with apical lamina wider distally (Figure 5) (Central Eastern Sardinia, Corrasi Mt.: Nurra 'e Pradu cave)....

ilianae sp. $\mathbf{n}$.

- $\quad$ Smaller in size (TL: 3.10 - $3.65 \mathrm{~mm}$; L: 3.40 - $3.86 \mathrm{~mm}$ ). median lobe of aedeagus smaller, with apical lamina more elongate and narrower distally (Figure 6) (Central Eastern Sardinia, Dorgali: Gurennoro or Pisanu cave) ....

henroti Jeannel, 1957

Anterior angles of both clypeus and pronotum rounded, slighly prominent in front; genae slightly convex (Central Eastern Sardinia, Seui: Is Diavolus cave)

elegans (Dodero, 1916) Anterior angles of both clypeus and pronotum very prominent in front; genae very convex, inflate Elytra shorter, ovate, with lateral sides rounded and lateral margins with markedly prominent and numerous (23-25) teeth. Median lobe of aedeagus markedly curved, with apical lamina shorter and rounded distally (Figure 3) (Central Eastern Sardinia, Dorgali: Bue Marino cave). monacha sp. $\mathbf{n}$.

- $\quad$ Elytra elongate, sub-parallel sided; lateral margins with slightly prominent and less numerous (14-16) teeth. Median lobe of aedeagus slightly curved, with apical lamina more developed and sub-truncate distally (Figure 4) (Central Eastern Sardinia: caves in the Gairo region)

onnisi Casale \& Magrini, 2004

Larger in size (TL: 2.31-2.50; L: 2.58-2.99). Elytra with lateral margins serrate in the basal third only. Median lobe of aedeagus with apical lamina short; endophallus with copulatory piece in the shape of twisted lamina (Central 
Eastern Sardinia: Sadali, Is Janas cave; Nurallao [Nuoro])

jana Leo, Magrini \& Fancello, 2005

- $\quad$ Smaller in size (TL: 1.99-2.22; L: 2.11-2.50). Elytra with lateral margins serrate from the humeral angle to apex. Median lobe of aedeagus with apical lamina markedly elongate and curved on the ventral side; endophallus with copulatory piece in the shape of triangular lamina, rounded distally and hollow at base. Central Eastern Sardinia, near Dorgali and Galtellì, in deep soil and caves

pandora (Holdhaus, 1924)

\section{Discussion}

\section{Reicheiina: current taxonomy, and biogeographical remarks at world scale.}

As recently recalled (Casale 2009), the current distribution of Reicheiina in the EuroMediterranean area and the African continent is highly interesting from the biogeographical point of view: in fact, this lineage presents a markedly disjoint distribution, being represented by several genera and many species in mainland and islands of this area, and some taxa in East Africa, West Africa, South Africa and Madagascar (Jeannel 1957; Basilewsky 1980, Casale and Vigna Taglianti 1996; Balkenhol 2003, 2005; Bulirsch et al. 2005; Bulirsch and Magrini 2007).

Grebennikov et al. (2009) stressed that the discovery of supposed Reicheiina in South-Eastern and Eastern Asia (Laos, Vietnam and Japan: Balkenohl 2005) (Figure 7) revealed a large gap in their known distribution and, implicitly, challenged the monophyly of the subtribe. The same authors recalled that, besides Reicheiina, other apparently unrelated representatives of the subfamily Scaritinae show reduced or absent eyes and wings, small size and depigmentation, in correlation with their subterranean way of life, and other blind Clivinini belong to the subtribe Clivinina (as the genus Trogloclivina Deuve, 2003 from Papua New Guinea).

Furthermore, these authors do not consider members of the subtribe Reicheiina some taxa cited as either potentially belonging, or closely related, to the subtribe Reicheiina: the monotypic genus Italodytes Müller, 1938 from Apulian caves, Syleter Andrewes, 1941 (including Afrotropical and Oriental species), Psilidius Jeannel, 1957 (including Afrotropical species), Leleuporella Basilewsky, 1956 (including Afrotropical species and one from Sri Lanka), Trilophus Andrewes, 1927 (including Oriental species) and Trilophidius Jeannel, 1957 (including Afrotropical and Oriental species).

\section{Biogeographical remarks at local scale.}

Two hypotheses have been proposed to explain the origin and the exceptional specific diversity of the genus Typhloreicheia in Sardinia. 


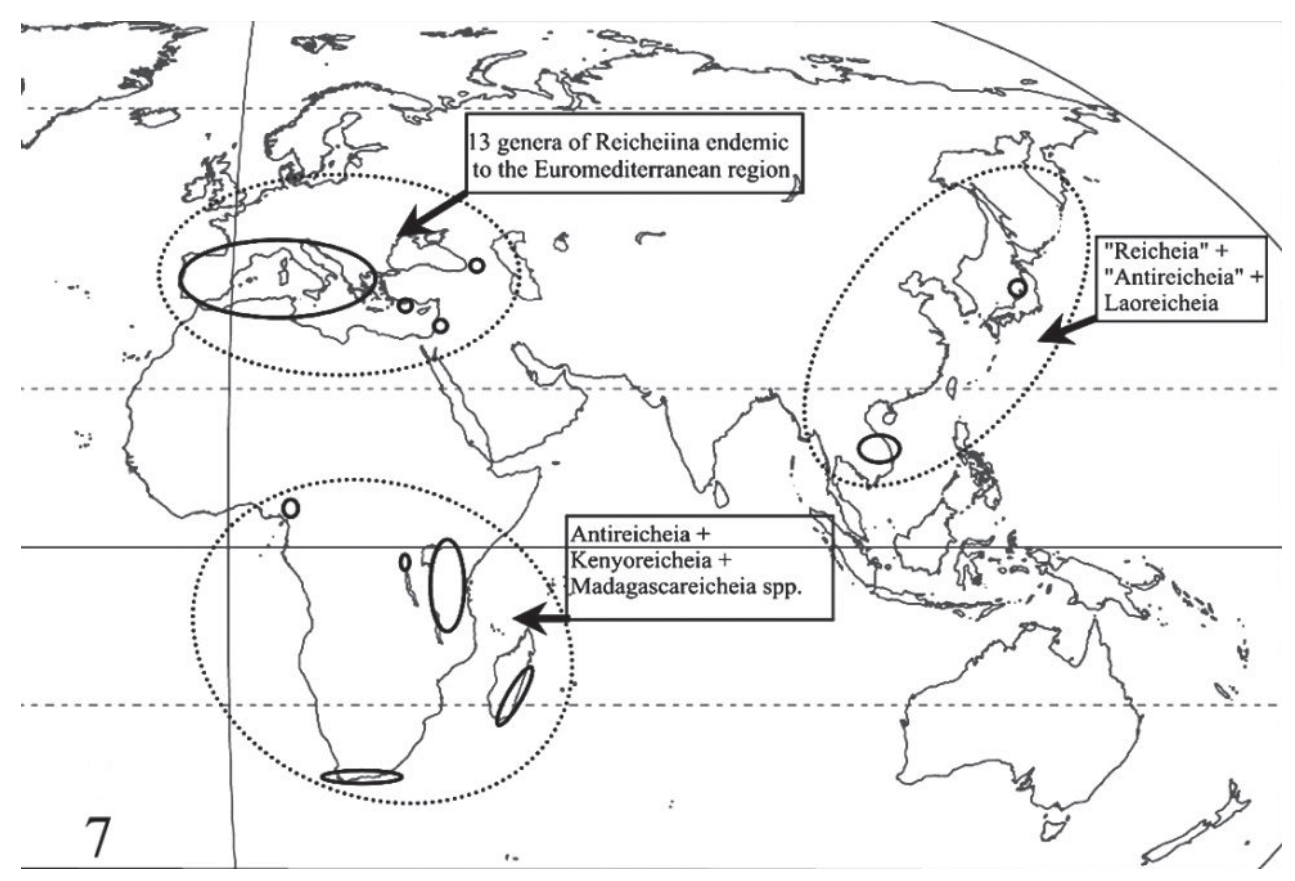

Figure 7. World distribution of the subtribe Reicheiina in the current sense.

The first hypothesis proposes at least two different, heterochronic colonisation events. The older one is represented by the common ancestor of the subgenus Sardoreicheia Jeannel, 1957. This subgenus was treated as synonym of Typhloreicheia by Casale and Vigna Taglianti (1996) and other authors, but separated again in the recent catalogues by Balkenhol (2003) and Lorenz (2005). The colonisation event originated from the Miocene tectonic drift of the Corso-Sardinian micro-plate in the Western Mediterranean (Alvarez 1972). Conversely, the more recent colonisation event of the common Apennine ancestor of Typhloreicheia sensu stricto occurred through land connections during the Messinian Salinity Crisis in the Mediterranen basin (Hsü et al. 1977).

This scenario should be similar to the process recently proposed by Wirta et al. (2010) concerning Scarabaeidae Scarabaeinae in Madagascar: in fact, this island has an exceptionally large fauna of more than 250 species of endemic dung beetles. Based on molecular phylogenies, the species descend from eight independent overseas colonisations, of which four have given rise to big radiations. Among them, the tribe Canthonini show three parallel radiations following the respective colonisations at 64-44 Mya.

The second hypothesis proposes that all Sardinian Typhloreicheia species are derived from a common Tyrrhenian, Miocene ancestor.

In other words, the question is: how many times have Reicheiina colonized the island of Sardinia? An adequate solution of this question based exclusively on morphological features is hardly possible. Involvement of molecular data might eventually help to generate complete phylogenetic hypotheses for Typhloreicheia and related genera and thus assist with detecting the number of colonisation events. 
The similarities between the male genitalia of some Sardinian species and those of species of the Apennine chain, the Elba island and Sicily, supports the hypothesis of multiple colonisations of the island by different ancestors. This is further strengthened by the remarkable absence of Typhloreicheia species in Corsica and Baleares, where the genus is replaced by Reicheia Saulcy, 1863. Furthermore, the scenario in Sardinia has been complicated by the recent description of the genus Dimorphoreicheia Magrini, Fancello \& Leo, 2003 (with two species known so far), characterised by the presence of setiferous pores on the disc of the pronotum, a feature previously thought to be peculiar to the genus Reicheadella Reitter, 1913, with some species distributed in the southern Balkans (Casale et al. 1998 a). Nevertheless, this highly complicated situation could be explained by any hypotheses treated below.

\section{Adaptive radiation of Typhloreicheia in Sardinia: previous and new hypotheses compared.}

Adaptive radiation might work very rapidly. Classic examples include Hawaiian silverswords and Drosophila, Darwin's finches on the Galápagos islands, Anolis lizards on Caribbean islands, and cichlids of the East African Great Lakes, among others (Givnish and Sytsma 1997; Schluter 2000; Gavrilets and Losos 2009). Gavrilets and Losos (2009) recognize two main components of adaptive radiation: the production of new species by allopatric or non-allopatric speciation, and their subsequent adaptation to a diversity of ecological niches. This may happen when an ancestral taxon finds itself in a vacant area, where resources are abundant and underutilized (e.g., islands or lakes).

The genus Typhloreicheia in Sardinia shows a spectacular diversity much exceeding that in all other Tyrrhenian areas (Iberian Peninsula, Baleares, Apennines, Sicily) where the genus is represented. This fact already induced Holdhaus (1924) and Jeannel (1957), even with much scarcer data to believe that "the genus should have originated in Sardinia". Some years later Magistretti (1965), in his catalogue of the carabid fauna of Italy, was able to list only 13 Typhloreicheia species from Sardinia, whereas they are presently 46 (see Figure 8 a, b).

Recent research in the field shows a scenario in which two, three or more sympatric Typhloreicheia species are present in every micro-sector of the island. Additionally, if they are living in the same area, they show different habitat choice (soil litter, deep soil, crevices, or caves, respectively), and different adaptive features to a subterranean way of life. A good example is offered by two cave-dwelling species, i.e. T. henroti Jeannel, 1957 and T. monacha sp. n., which in the Dorgali area (Central-Eastern Sardinia) co-occur with the endogean T. doderoi (Holdhaus, 1924) and T. pandora (Holdhaus, 1924). In close areas, other so-called "troglobitic" species (sampled in caves only) are reported from the Jurassic massifs of the central-eastern part of the island, where many highly specialized subterranean taxa are localized: T. elegans (Dodero, 1916), T. onnisi Casale \& Magrini, 2004, and T. ilianae sp. n. described above (Figure 9). 


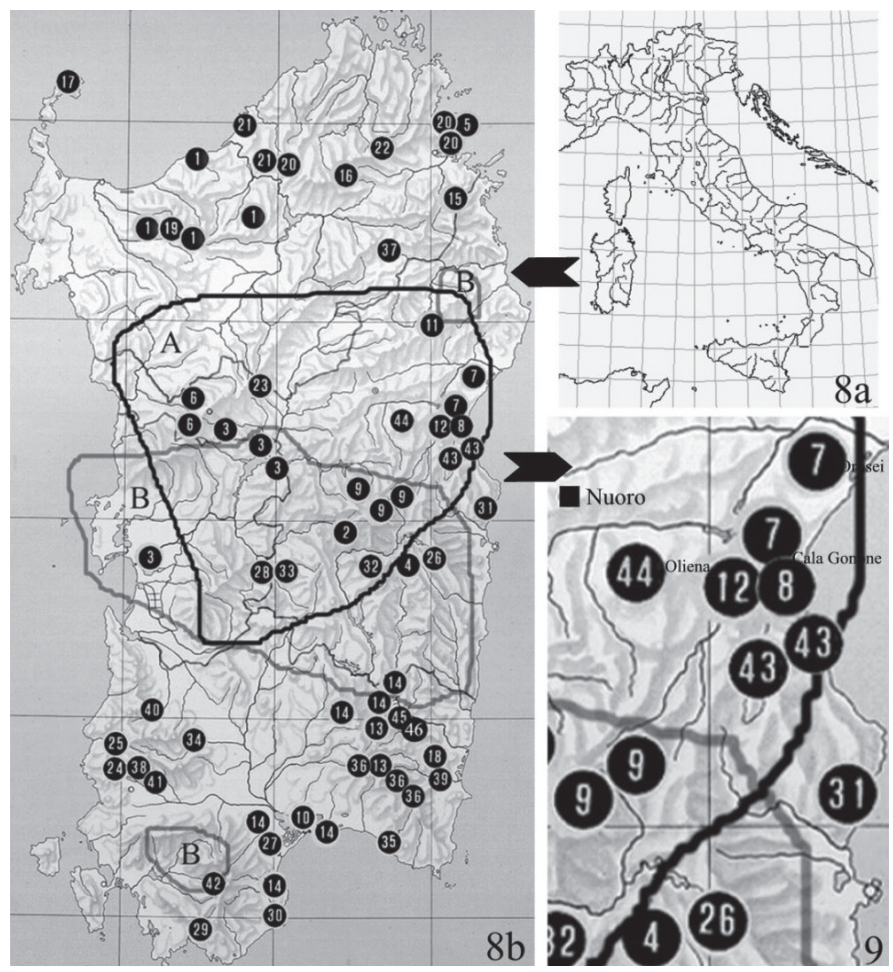

Figures 8-9. 8 Geographical distribution of Typhloreicheia species known so far in Sardinia. Numbers in the map indicate the locality of each species, in chronological order of description. A and B, and related lines, indicate the range of the only two species with wider distribution in the island. A - Typhloreicheia denticulata (Holdhaus, 1924) sensu lato B - Typhloreicheia jucunda (Holdhaus, 1924) sensu lato; 1 - T. raymondi (Putzeys, 1869); 2 - T. sardoa (Baudi, 1891); 3 - T. kraussei (Reitter, 1914); 4 - T. elegans (Dodero, 1916); 5 - T. parallela (Holdhaus, 1924); 6 - T. manto (Holdhaus, 1924); 7 - T. pandora (Holdhaus, 1924); 8 - T. doderoi (Holdhaus, 1924); 9 - T. monticola (Holdhaus, 1924); 10 - T. occulta (Holdhaus, 1924); 11 - T. minima (Binaghi, 1936); 12 - T. henroti Jeannel, 1957; 13 - T. fausti Fancello, 1988; 14 - T. valeriae Fancello, 1988; 15 - T. fancelloi Magrini, 2000; 16 - T. melonii Magrini, 2001; 17 - T. arganoi Vigna Taglianti, 2001; 18 - T. viti Magrini \& Bulirsch, 2002; 19 - T. vignai Magrini, 2003; 20 - T. consortii Magrini, 2003; 21 - T. degiovannii Magrini, 2003; 22 - T. nadiae Magrini, 2003; 23 - T. cirocchii Magrini, 2003; 24 - T. angelae Magrini, 2003; 25 - T. leoi leoi Magrini, 2003; 26 - T. onnisi Casale \& Magrini, 2004; 27 - T. laurentii Magrini, 2004; 28 - T. medusa Magrini \& Fancello, 2005; 29 - T. tegulae Leo, Magrini \& Fancello, 2005; 30 - T. exilis Leo, Magrini \& Fancello, 2005; 31 - T. supramontis Leo, Magrini \& Fancello, 2005; 32 - T. jana Leo, Magrini \& Fancello, 2005; 33 - T. eleonorae Leo, Magrini \& Fancello, 2005; 34 - T. tanit Leo, Magrini \& Fancello, 2005; 35 - T. regina Leo, Magrini \& Fancello, 2005; 36 - T. pellita Leo, Magrini \& Fancello, 2005; 37 - T. rocchii Magrini \& Degiovanni, 2006; 38 - T. holdhausi Magrini, Fancello \& Casale, 2006; 39 - T. petriolii Magrini \& Fancello, 2007; 40 - T. abbazzii Magrini \& Fancello, 2007; 41 - T. leoi pilosa Magrini \& Fancello, 2007; 42 - T. sebera Magrini \& Fancello, 2009; 43- T. monacha sp. n. Casale \& Marcia; 44 - T. ilianae sp. n. Casale \& Marcia; 45 - T. sp. n. Magrini, Marcia \& Casale in litteris; 46 - T. sp. n. Magrini, Marcia \& Casale in litteris (original by P. Magrini, updated with unpublished data). 9 Detail of the map of geographical distribution of Typhloreicheia species in Sardinia, showing the high concentration of sympatric species in the centraleastern part of the island. 
Casale (2009) suggested that Reicheiina in Sardinia form a remarkably speciose and diversified group through the process of adaptive radiation. This diversity originated from one or two colonisation events (see above, paragraph 2 of Discussion). Such might be explanation of the high number of Typhloreicheia species in Sardinia, and their so far inexplicable relationships of the species in the adjacent territories.

Greve et al. (2010) performed an exhaustive study, based on molecular data, on the land snails of the genus Theba (Gastropoda: Helicidae) in the Canary Islands. They demonstrated that the main mode of diversification was intra-archipelago speciation rather than independent colonization of the islands from the mainland. The phylogenetic reconstruction inferred a Canarian origin for Theba. The islands, however, must have been colonized once from the mainland (North Africa or Iberian peninsula), but neither fossils nor living descendants of a continental ancestor of Theba have been found so far. Divergence time estimates suggested an evolution of Theba in the Canarian archipelago and an initial radiation during the Late Oligocene/Early Miocene. Species from Morocco are nested among species from the Canary Islands, suggesting re-colonization of the continent from the islands. If so, then re-colonization of NW Africa during the Middle Miocene led to a remarkable continental radiation, suggesting a rare example of re-colonization of the mainland from oceanic islands (Bellemain and Ricklefs 2008).

A similar process - e.g. the colonization of Sardinia by a continental Reicheia-like ancestor, maybe of Iberian origin through the rotation of the Corsica-Sardinia microplate (Alvarez 1972), an adaptive radiation in the island, the extinction of the colonizer on the continent, and then a re-colonization of the close, circum Mediterranean-areas through land connections during the Messinian Salinity Crisis in the Mediterranen basin (Hsü et al. 1977) cannot be excluded. In fact Reicheiina, for their peculiar distribution in the Euro-Mediterranean area, appear as a remarkably ancient lineage of Paleo-Mediterranean, Tertiary forest dweller scaritid beetles, in which remote cladogenetic events are presently documented by distribution of their relic, sometimes monotypic extant genera.

\section{Conclusions}

Available data, and discoveries in progress (including two further species not yet described, but indicated in the map of Figure 8), suggest several reasons to hypothesize that Reicheiina in Sardinia formed a remarkably diversified clade through the process of adaptive radiation.

The speciation events that produced these taxa should have been originated by isolation of small populations in micro-geographic areas, in deep soils and caves, and an exceptional extent of adaptive colonisation and diversification into a variety of soil and underground compartments and ecological niches induced by the Plio-Pleistocene climatic changes, with some cases of subsequent overlap of distributions in wet, forested phases (Casale 2009).

The hypothesis here proposed, that Typhloreicheia (in the current sense) radiated in Sardinia, and then re-colonized the close, circum-Mediterranean islands and main- 
land, remains of course a mere hypothesis, that should be tested. Unfortunately, as recalled in Introduction, the study of this group is difficult owing both to the small sizes of its representatives, and particularly the scarcity of material, some taxa being known from a few or only one specimens, so that molecular data on them - like fossils, or larval stages - are so far fully absent. Therefore, future investigations will need further, strong efforts both in the field and laboratory.

\section{Acknowledgements}

We are particularly indebted to our good friend Paolo Magrini (Florence), for providing some of the illustrations to this paper, and for data, discussion, and pleasant days in the field in Sardinia. For the loan of material, the assistance both in the field and in laboratory, and information on which the present contribution is based, we thank all those who helped us in several years of study of the subterranean Sardinian fauna: in particular, concerning the present contribution, Giuseppe Grafitti, Enrico Lana, Roberto Loru, Alessandro Molinu, Carlo Onnis, Laura Sanna and Fabio Stoch. A great acknowledgement is due to Vasily Grebennikov (Ottawa), for suggestions, corrections and improvements to the original manuscript. We thank also Stefano Birindelli for identification of terrestrial snails.

Research was in part supported by grants INTERREG 3 (Sardinia-Corsica-Tuscany), PRIN projects of the Italian Ministry of the University and Scientific Research ("Zoogeography of Mediterranean - Southern African disjoint distributions by a multimethod approach" and "The endemism in Italy"). P. Marcia has received support from Regione Sardegna through a grant co-financed with funding from the PO Sardegna FSE 2007-201 L.R.7/2007 "Promozione della ricerca scientifica e dell'innovazione tecnologica in Sardegna”.

\section{References}

Alvarez W (1972) Rotation of the Corsica-Sardinia microplate. Nature Physical Science 235: 103- 105.

Balkenohl M (2003) Subfamily Scaritinae Bonelli, 1810, pp. 219-234. In: Löbl L \& Smetana A (Eds), Catalogue of Palearctic Coleoptera. Vol. 1. Archostemata - Myxophaga - Adephaga. Apollo Books, Stenstrup.

Balkenohl M (2005) First record of Reicheiina species from the Oriental Region and Japan (Coleoptera, Carabidae, Scarititae, Clivinini). Coleoptera 9: 1-10.

Basilewsky P (1980) Les Reicheiina de l'Afrique du Sud (Coleoptera: Carabidae). Entomologia Generalis 6: 293-302.

Bellemain E, Ricklefs RE (2008) Are islands the end of the colonization road? Trends Ecology Evolution 23: 536-537. doi: 10.1016/j.tree.2008.05.001 
Bulirsch P, Janák J, Moravec P (2005) New species and findings of Scaritinae (Coleoptera: Carabidae) from Madagascar. Studies and reports of District Museum Prague-East. Taxonomical Series 1 (1-2): 1-35.

Bulirsch P, Magrini P (2007) Descriptions of four new species and Kenyoreicheia gen. n. of the subtribe Reicheiina (Coleoptera: Carabidae: Scaritinae) from East Africa. Studies and reports of District Museum Prague-East. Taxonomical Series 3 (1-2): 17-30.

Casale A (1985) Note su Typhloreicheia italiane, con descrizione di nuovi taxa di Sicilia (Col. Carabidae, Scaritinae). Annali del Museo Civico di Storia Naturale "Giacomo Doria”, Genova 85: 259-271.

Casale A (2009) Adaptive radiation in Mediterranean islands? The case of Reicheiina in Sardinia (Coleoptera, Carabidae, Scaritinae), pp. 75-88. In: Casellato S, Burighel P \& Minelli A (Eds), Life and Time. The Evolution of life and its History, Cleup, Padova.

Casale A, Di Giulio A, Marcia P, Molinu A (2010) The third instar larva of Speomolops sardous Patrizi, 1955, a cave-dwelling molopine beetle endemic to Eastern Sardinia, with notes on its habitat (Coleoptera, Carabidae). Italian Journal of Zoology, 77 (2): 159-167. doi: 10.1080/11250000903015182

Casale A, Giachino PM, Jalžić B, Vailati D (1998a) Reicheiina nuovi o poco noti dell'area mediterranea orientale (Coleoptera Carabidae Scaritinae). Annali del Museo civico di Scienze naturali, Brescia 31: 87-104.

Casale A, Grafitti G, Lana E, Marcia P, Molinu A, Mucedda M, Onnis C, Stoch F (2008) La Grotta del Bue Marino: cinquanta anni di ricerche biospeleologiche in Sardegna. Atti XX Congresso Nazionale di Speleologia (Iglesias, 2007), Memorie dell'Istituto italiano di Speleologia, Bologna (S. II) XXI: 197-209.

Casale A, Magrini P (2004) Una nuova specie di Typhloreicheia del "gruppo elegans" della Sardegna centro-orientale, con note sulla tassonomia, sulla filogenesi e sulla distribuzione del genere in Sardegna (Coleoptera Carabidae Scaritinae). Redia 86 (2003): 47-52.

Casale A, Vigna Taglianti A (1996) Coleotteri Carabidi di Sardegna e delle piccole isole circumsarde, e loro significato biogeografico (Coleoptera, Carabidae). Biogeographia 18 (1995): 391-427.

Casale A, Vigna Taglianti A, Juberthie C (1998b) Coleoptera Carabidae. In: Juberthie C, Decu V (Eds) Encyclopaedia Biospeologica, II. Société Internationale de Biospéologie, Moulis, France, 1047-1081.

Fancello L (1988) Due nuovi Scaritini endogei della Sardegna meridionale (Coleoptera Carabidae). Bollettino della Società entomologica italiana 120: 4-10.

Gavrilets S, Losos J B (2009) Adaptive radiation: contrasting theory with data. Science 323: 732-737. doi: 10.1126/science. 1157966

Giachino PM, Vailati D (2010) The subterranean environment. Hypogean life, concepts and collecting techniques. WBA Handbooks, 3, Verona, 132pp.

Givnish T, Sytsma K (1997). Molecular evolution and adaptive radiation. Cambridge University Press, New York.

Grebennikov V, Bulirsch P, Magrini P (2009) Discovery of Antireicheia in Cameroon with description of four new species and discussion on phylogeny and distribution of endogean Reicheiina (Coleoptera: Carabidae: Scaritinae: Clivinini). Zootaxa 2292: 1-14. 
Greve C, Hutterer R, Groh K, Haase M, Misof B (2010) Evolutionary diversification of the genus Theba (Gastropoda: Helicidae) in space and time: A land snail conquering islands and continents. Molecular Phylogenetics and Evolution 57 (2010): 572-584. doi: 10.1016/j. ympev.2010.08.021

Holdhaus K (1924) Monographie du genre Reicheia Saulcy (Coleoptera Carabidae). Abeille 32: $161-220$.

Hsü KJ, Montadert L, Bernouilli D, Cita MB., Erickson A, Garrison RE, Kidd RB, Melieres F, Müller C, Wright R (1977) History of the Mediterranean salinity crisis. Nature 267: 399-403. doi: 10.1038/267399a0

Jeannel R (1957) Révision des petits scaritides endogés voisins de Reicheia Saulcy. Revue française d'Entomologie 24: 129-212.

Leo P, Magrini P \& Fancello L (2005) Materiali per lo studio delle Typhloreicheia della Sardegna con descrizione di nove specie nuove (Coleoptera Carabidae). Bollettino della Società entomologica italiana 137 (3): 167-203.

Liebherr JK, Will KW (1998) Inferring phylogenetic relationships within Carabidae (Insecta, Coleoptera) from characters of the female reproductive tract. In: Ball G E, Casale A, Vigna Taglianti A (Eds) Phylogeny and classification of Caraboidea (Coleoptera: Adephaga). Proceedings of a Symposium (28 August, 1996, Florence, Italy), XX International Congress of Entomology. Atti Museo regionale di Scienze naturali, Torino, 107-170.

Lorenz W (2005) Systematic list of extant ground beetles of the world (Insecta Coleoptera "Geadephaga": Trachypachidae and Carabidae. incl. Paussinae, Cicindelinae, Rhysodinae). Tutzing, iv + 530 pp.

Magistretti M (1965) Coleoptera. Cicindelidae, Carabidae. Catalogo topografico. Fauna d'Italia, 8. Calderini, Bologna, 512 pp.

Magrini P, Fancello L (2007) Typhloreicheia della Sardegna: descrizione di tre nuovi taxa e dati geonemici inediti (Coleoptera, Carabidae). Fragmenta entomologica 39: 161-178.

Magrini P, Fancello L, Leo P (2003) Un nuovo genere e una nuova specie di Reicheiina della Sardegna (Coleoptera Carabidae Scaritinae). Redia 84 (2001): 141-149.

Schluter D (2000) The ecology of adaptive radiation. Oxford University Press, Oxford. Vigna Taglianti A (2001) I Carabidi delle isole circumsarde (Coleoptera, Carabidae). Annali del Museo civico di Storia naturale "Giacomo Doria”, Genova 93 (2000): 305-428.

Vigna Taglianti A (2005) Checklist e corotipi delle specie di Carabidae della fauna italiana. Appendice B. In: Brandmayr P, Zetto T, Pizzolotto R (Eds) I Coleotteri Carabidi per la valutazione ambientale e la conservazione della biodiversità. Manuali e linee guida 34, APAT, Roma, 186-225.

Wirta H, Viljanen H, Orsini L, Montreuil O, Hanski I (2010) Three parallel radiations of Canthonini dung beetles in Madagascar. Molecular Phylogenetics and Evolution 57 (2010): 710-727. doi: 10.1016/j.ympev.2010.08.013

Zapparoli M (2009) An annotated catalogue of the epigeic and cave centipedes (Chilopoda) of Sardinia, pp. 56-168. In: Cerreti F, Mason F, Minelli S, Nardi G, Whitmore D (Eds). Research on the Terrestrial Arthropods of Sardinia (Italy). Zootaxa, 2318, 1-602. 